\title{
Anti-hepatoma activities of ethyl acetate extract from Ampelopsis sinica root
}

\author{
JIA-ZHI WANG ${ }^{1,2}$, BI-SHENG HUANG ${ }^{1}$, YAN CAO $^{1}, \mathrm{KE}-L I ~ C H E N^{1}$ and JUAN LI ${ }^{1}$ \\ ${ }^{1}$ Key Laboratory of Education Ministry on Traditional Chinese Medicine Resource and Compound Prescription, \\ Hubei University of Chinese Medicine, Wuhan, Hubei $430065 ;{ }^{2}$ College of Pharmacy, \\ Hubei University of Medicine, Shiyan, Hubei 442000, P.R. China
}

Received September 10, 2016; Accepted February 13, 2017

DOI: $10.3892 /$ or.2017.5504

\begin{abstract}
Ampelopsis sinica root (ASR) is a known hepatoprotective folk traditional Chinese medicine. The anti-hepatoma activity of ethyl acetate extract from $A$. sinica root (ASRE) in vitro and in vivo and its possible mechanism were explored. This study was designed to investigate cytotoxicity by MTT assay, induction of apoptosis via Hoechst 33258 staining, scanning electron microscopy and bivariate flow cytometric analysis (Annexin V-FITC/PI), inflammation and apoptosis related genes expression by RT-PCR and p53 protein expression by immunofluorescence assay in HepG2 cells. Then, the antitumor activity in vivo was detected by hepatoma H22 xenograft tumor in mice. The results showed that ASRE had powerful anti-hepatoma activity in vitro without obvious toxicity on normal cells and could induce HepG2 cell apoptosis. The mechanism may be associated with downregulation of inflammatory cytokines including cyclooxygenase-2, 5-lipoxygenase and FLAP, increase of the ratio of bax/bcl-2, activation caspase-3 and inhibition of survivin, and increased expression of p53 protein. Furthermore, the HPLC assay showed the main compounds of ASRE were gallic acid, catechin and gallic acid ethyl ester. In animal experiments, ASR ethanol extract decreased the tumor
\end{abstract}

Correspondence to: Professor Ke-Li Chen or Dr Juan Li, Key Laboratory of Education Ministry on Traditional Chinese Medicine Resource and Compound Prescription, Hubei University of Chinese Medicine, Wuhan, Hubei 430065, P.R. China

E-mail: kelichen@126.com

E-mail: 1z198207@126.com

Abbreviations: ASR, Ampelopsis sinica (Miq.) W.T. Wang root; ASRE, ethyl acetate extract from Ampelopsis sinica root; PI, propidium iodide; MTT, 3-(4,5-dimethylthiazol-2-yl)-2,5-diphenyltetrazolium bromide; DMSO, dimethyl sulfoxide; FBS, fetal bovine serum; $\mathrm{IC}_{50}$, concentration of $50 \%$ inhibition; SEM, scanning electron microscopy; COX, cyclooxygenase; LOX, lipoxygenase; PS, phosphatidylserine; HCC, hepatocellular carcinoma

Key words: Ampelopsis sinica root, anti-hepatoma, ethyl acetate extract, apoptosis, mechanism weights of hepatoma H22 tumor-bearing mice. Therefore, ASR may be a potential therapeutic agent in the treatment of hepatocellular carcinoma.

\section{Introduction}

Ampelopsis sinica (Miq.) W.T. Wang, belongs to the genus of Ampelopsis (Vitaceae family), the root of which has been used as folk traditional Chinese medicine for heat-clearing and detoxifying, antibacterial and antivirus, and trauma disease. In 1987, Yang et al documented that A. sinica root could significantly decrease elevated glutamic-pyruvic transaminase (GPT) level caused by carbon tetrachloride and galactosamine (1). According to Japanese patent publication, A. sinica root contains an effective anti-hepatic fibrosis element. Studies worldwide indicate that the extracts of $A$. sinica root has significant effects on hepatoprotection, descending transaminase, anti-hepatitis $\mathrm{B}$ virus and suppressing free radical damage (2-6). Thus, we speculated that $A$. sinica root has anti-hepatoma activity.

Our 3-(4,5-dimethylthiazol-2-yl)-2,5-diphenyltetrazolium bromide (MTT) pilot experiments showed that the ethyl acetate part of $A$. sinica root had the best antitumor activity compared to petroleum ether, n-butyl alcohol and water-soluble part. This experimental study was performed to investigate the suppression effects of the ethyl acetate extract of $A$. sinica root on growth of HepG2 cells and to clarify the possible mechanism of its anti-hepatoma activity.

\section{Materials and methods}

Plant material preparation and extraction. A. sinica root (ASR) was collected in August 2013 from Macheng in Hubei. It was authenticated by Professor Keli Chen and the voucher specimens were deposited in the herbarium of Hubei University of Chinese Medicine (Wuhan, China). The ethanol extract was prepared as previously described (2). The total ethanol extract was extracted with ethyl acetate to obtain the A. sinica root ethyl acetate extract (ASRE) which was lyophilized and dissolved in dimethyl sulfoxide (DMSO) for use in the follow-up experiments. The purity of ASRE was $\sim 1.5 \%$.

Reagents and cell cultures. Acetonitrile (chromatographically pure) and formic acid (mass spectrum magnitude) were 
obtained from Thermo Fisher Scientific, Inc. (Waltham, MA, USA). Gallic acid (batch lot. 110831-201204) and catechin (batch lot. 878-200102) were purchased from the National Institute for the Control of Pharmaceutical and Biological Products (Beijing, China).

Dulbecco's modified Eagle's medium (DMEM), trypsin and penicillin/streptomycin were obtained from Gibco (Grand Island, NY, USA). Fetal bovine serum (FBS) was purchased from HyClone (Logan, UT, USA). TRIzol, MTT and DMSO were from Sigma-Aldrich (St. Louis, MO, USA). All chemicals and reagents were of analytical reagent grade. HepG2, hepatocellular carcinoma (HCC); A549, lung carcinoma; PC3, prostate carcinoma; MCF7, breast carcinoma; MGC803, gastric carcinoma; and HL-7702, normal human liver cells were obtained from China Center for Type Culture Collection of Wuhan University (Wuhan, China). All the cells were routinely cultured in DMEM supplemented with $10 \% \mathrm{FBS}$ and $1 \%$ streptomycin/penicillin at $37^{\circ} \mathrm{C}$ in a humidified incubator with $5 \% \mathrm{CO}_{2}$ under saturating humidity. The cells were subcultured with $0.25 \%$ trypsin when they were $80 \%$ confluent. Then, the cells in exponential growth phase were collected for the following experiments.

UPLC-Q-TOF MS E analysis. ACQUITY UPLC/Xevo G2-XS QTof system coupled with an ACQUITY UPLC HSS T3 (50 mm x $2.1 \mathrm{~mm}, 1.7 \mu \mathrm{m}$ ) was used for the component analysis of ASRE. The mobile phase was composed of solvent A ( $0.1 \%$ formic acid in water) and solvent B (acetonitrile). The optimized elution conditions were as follows: $0.00-1.50 \mathrm{~min}$, 5-23\% B; $1.50-4.00 \mathrm{~min}, 23 \% \mathrm{~B} ; 4.00-7.00 \mathrm{~min}, 23-95 \% \mathrm{~B}$. The column temperature was maintained at $45^{\circ} \mathrm{C}$. The flow rate was set at $500 \mu \mathrm{l} / \mathrm{min}$. The injection volume was $2 \mu \mathrm{l}$.

Leucine enkephaline was used for the lock mass. Each sample was analyzed in ESI mode. The scan range was from 50 to $2,000 \mathrm{~m} / \mathrm{z}$. Desolvation gas flow and cone gas flow were set at 600 and $50 \mathrm{l} \cdot \mathrm{h}^{-1}$, respectively. The source temperature and the desolvation temperature were set at 100 and $450^{\circ} \mathrm{C}$, respectively. The capillary and cone voltage were set at $0.5 \mathrm{kV}$ and $40 \mathrm{~V}$, respectively. An alternation low-energy scan (off) and high-energy scan (collision energy ramped from 15 to $30 \mathrm{eV}$ ) were used to acquire the precursor (MS) and their fragments $\left(\mathrm{MS}^{\mathrm{E}}\right)$ in ESI- mode. The instrument was controlled with MassLynx 4.1 software (Waters Corporation, Milford, MA, USA).

Cell viability assay. The in vitro antitumor activity of ASRE was assessed by MTT assay as described in detail elsewhere (7) on five different cancer cell lines. Briefly, the logarithmic growth phase cells were dispensed into a 96-well microplate at a density of $2 \times 10^{4}$ cells $/ \mathrm{ml}$ and cultured at $37^{\circ} \mathrm{C}$ in $5 \% \mathrm{CO}_{2}$. Then the cells were exposed to ASRE at various concentrations ranging from 12.5 to $100 \mu \mathrm{g} / \mathrm{ml}$ for $72 \mathrm{~h}$ and the wells without ASRE treatment were considered as control. After the exposure period, the cells were cultured for an additional $4 \mathrm{~h}$ with $0.5 \mathrm{mg} / \mathrm{ml}$ MTT to product formazan. Then, $100 \mu 1$ DMSO was added to each well to dissolve the formed formazan crystals. An automated microplate reader was used to determine the optical density at a wavelength of $490 \mathrm{~nm}$. Relative cell growth inhibition rate $(\%)=\left(1-\mathrm{OD}_{\text {treated }} / \mathrm{OD}_{\text {control }}\right) \times 100 \%$ (8). Cytotoxicity was evaluated by $\mathrm{IC}_{50}(50 \%$ inhibition of viability) which was obtained from a regression analysis of dose-response curves. Assays were done with 3 parallel wells on three independent trials.

Inverted microscope observation. HepG2 cells were seeded into 24-well plates and cultured overnight, followed by exposed to different doses of ASRE $(0,50,75$ and $100 \mu \mathrm{g} / \mathrm{ml})$. The morphological changes and growth status were observed and photographed using inverted light microscopy (IX73; Olympus, Tokyo, Japan).

Hoechst 33258 staining test. Hoechst 33258 staining was used to observe the morphology of apoptotic cells, as previously described (9). The $1 \times 10^{5}$ cells $/ \mathrm{ml}$ exponentially growing HepG2 cells were seeded in 6-well plates and incubated for $24 \mathrm{~h}$. After the cells treated with various concentrations of ASRE $(0,50,75$ and $100 \mu \mathrm{g} / \mathrm{ml})$ for $24 \mathrm{~h}$, the cells were fixed with $70 \%$ ethanol for $20 \mathrm{~min}$ at room temperature. Then, after being washed with phosphate-buffered saline (PBS), the cells in each well were stained with $0.5 \mathrm{ml}$ Hoechst 33258 solution at room temperature for $5 \mathrm{~min}$. The cells were photographed under a inverted fluorescence microscopy (IX73; Olympus) at $\times 400$ magnification to observe morphological changes after being washed with PBS.

Scanning electron microscopy (SEM) observation. In order to accurately observe the details of morphologic changes of HepG2 cells treated with different concentrations of ASRE, the SEM observation was determined as previously described (10) with slight modifications. Briefly, HepG2 cells were cultured on sterile glass slides to cell slides. The slides of cells with or without ASRE were fixed with 2.5\% glutaraldehyde overnight, and then fixed with $1 \%$ osmic acid for $4 \mathrm{~h}$ after several washes with PBS. The slides dehydrated in an ethanol series and dried with the lyophilizer. After gold sputtering, the slides were detected by a SEM (JSM-6501; JEOL Ltd., Tokyo, Japan).

Flow cytometry analysis. HepG2 cells were seeded into 6-well plates and cultured overnight. Then the cells were treated with ASRE at different concentrations $(0,50,75$ and $100 \mu \mathrm{g} / \mathrm{ml})$ for $24 \mathrm{~h}$ or treated with ASRE at $75 \mu \mathrm{g} / \mathrm{ml}$ for different times $(0$, 12,18 and $24 \mathrm{~h}$ ). After drug incubation time, all cells were harvested with trypsin and washed twice with PBS, and resuspended in $400 \mu \mathrm{l}$ Annexin $\mathrm{V}$ binding buffer. Then the cells were stained with $5 \mu$ l Annexin V-FITC for 15 min and $10 \mu \mathrm{l}$ propidium iodide (PI) for $5 \mathrm{~min}$ at $4^{\circ} \mathrm{C}$. This assay was performed exactly as indicated in the manufacturer's instructions of the Annexin V-FITC Cell Apoptosis Detection kit (BestBio, Shanghai, China). A FACSCalibur flow cytometer (Becton-Dickinson, San Jose, CA, USA) was used to detect fluorescence and the percentage of apoptotic cells were calculated by the internal software system of the FACSCalibur. Approximately $10^{4}$ cells were analyzed for each trail.

RT-PCR analysis. TRIzol was used to extract total cellular RNA from HepG2 cultured as above in the presence of ASRE for indicated time (0, 1.5, 3, 6, 9 and $12 \mathrm{~h})$. Cells were grown without ASRE as control. RNA quantity and purity were assessed by UV spectrophotometer (TU-1901; Beijing Purkinje General Instrument Co., Ltd., Beijing, China) 
Table I. Primer list.

\begin{tabular}{lll}
\hline Genes & \multicolumn{1}{c}{ Forward primer $\left(5^{\prime}-3^{\prime}\right)$} & \multicolumn{1}{c}{ Reverse primer $\left(5^{\prime}-3^{\prime}\right)$} \\
\hline 5 -LOX & GCCTCCCTGTGCTTTCC & ACCTGGTCGCCCTCGTA \\
FLAP & GCTGCGTTTGCTGGACTGATGTA & TAGAGGGGAGATGGTGGTGGAGAT \\
COX-2 & TATGAGTGTGGGATTTGACCAG & TCAGCATTGTAAGTTGGTGGAC \\
bcl-2 & GTGGAGGAGCTCTTCAGGGA & AGGCACCCAGGGTGATGCAA \\
bax & GGCCCACCAGCTCTGAGCAGA & GCCACGTGGGCGTCCCAAAGT \\
Caspase-3 & ATGGAGAACACTGAAAACTCAGT & TTAGTGATAAAAATAGAGTTCTTTTGT \\
Survivin & ATGGGTGCCCCGACGTTGCCCCCT & TCAATCCATGGCAGCCAGCTGCTCG \\
\hline -actin & TGACGTGGACATCCGCAAAG & CTGGAAGGTGGACAGCGAGG
\end{tabular}

5-LOX, 5-lipoxygenase; COX-2, cyclooxygenase-2.

based on the absorbance measurement at 260 and $280 \mathrm{~nm}$. Total RNA $(1.5 \mu \mathrm{g})$ was quantitated and then was reverse transcribed with a Script RT kit (Tiangen Biotech Co., Ltd., Beijing, China) according to the manufacturer's instructions to synthesise complementary DNA (cDNA). The levels of cyclooxygenase-2 (COX-2), 5-lipoxygenase (5-LOX), FLAP, bax, bcl-2, caspase-3 and survivin mRNA expression were measured by RT-PCR using Tiangen SuperReal PreMix Plus (Tiangen Biotech Co., Ltd.) with specific primers (Table I). The actin gene was used as reference gene. The $20 \mu 1$ reaction system contained $1 \mu \mathrm{l}$ resulting cDNA template, $1 \mu \mathrm{l}$ of specific sense primer, $1 \mu \mathrm{l}$ of specific antisense primer and $10 \mu 1$ 2X SYBR-Green SuperReal PreMix Plus, $7 \mu 1$ RNasefree $\mathrm{ddH}_{2} \mathrm{O}$. PCR amplification was initiated by $15 \mathrm{~min}$ of denaturation at $95^{\circ} \mathrm{C}$, and then followed by 40 cycles of $95^{\circ} \mathrm{C}$ for $10 \mathrm{sec}, 59-63^{\circ} \mathrm{C}$ (annealing temperature) for $20 \mathrm{sec}$ and $72^{\circ} \mathrm{C}$ for $30 \mathrm{sec}$, and a final incubation at $72^{\circ} \mathrm{C}$ for $5 \mathrm{~min}$. All RT-PCR reactions for each sample were performed in duplicate. The obtained cycle threshold number of each gene ( $\mathrm{Ct}$ value) was normalized into fold of relative changes according to the equation of $2^{-\Delta \Delta C T}$ method (11). The amplification products were analyzed on $1 \%$ agarose gel electrophoresis in $1 \mathrm{X}$ TAE buffer by ethidium bromide staining.

Immunofluorescent assay. HepG2 cells were cultured on sterile glass slides in 6-well plates. After $60 \%$ confluency, the cells were exposed to varying concentrations of ASRE $(0,50,75$ and $100 \mu \mathrm{g} / \mathrm{ml}$ ) for $24 \mathrm{~h}$. Cells were removed from the culture medium and washed 3 times with cold PBS. Then the cells in each well were fixed with $70 \%$ ice-cold ethanol in PBS at room temperature for $20 \mathrm{~min}$. Triton X-100 (0.1\%) in PBS was used to enhance the permeability of HepG2 cell membrane. The cells slides were blocked with $10 \%$ normal goat serum (Boster Biotechnology Co., Ltd., Wuhan, China) in the wet box for $1 \mathrm{~h}$ at room temperature after PBS washed 3 times for 5 min each. One hour later, the cells were washed gently with PBS and then incubated with the primary antibody, p53 antibody (FL-393; Santa Cruz Biotechnology, Inc., Santa Cruz, CA, USA) which is a rabbit polyclonal $\mathrm{IgG}$, in the wet box at $4^{\circ} \mathrm{C}$ overnight. After the primary antibody incubation steps, HepG2 cell slides were gently washed in PBS at least 3 times for 5 min each and then incubated with the FITC fluorescent-labeled goat anti-rabbit secondary antibody (Boster Biotechnology Co.,
Ltd.) in the wet box for $30 \mathrm{~min}$ at room temperature away from light. At the end of the immunofluorescent assay, the cells climbing should be always extensively washed with PBS, at least 3 times for $5 \mathrm{~min}$ each, and then should be dropped in antifade solution to avoid the attenuation of the FITC fluorescent. The samples were observed by an inverted fluorescence microscope (IX73; Olympus) at x200 magnification.

In vivo antitumor activity. Kunming mice (male, $20 \pm 2 \mathrm{~g}$ ) were procured from the Center of Experimental Animals in Wuhan University (Wuhan, China). The animal experimental protocol was approved by the Institutional Animal Care and Use Committee and the local experimental Ethics Committee (Laboratory Animal Certificate no. SYXK 2012-0068). The in vivo antitumor activity of ASR ethanol extract was further tested in hepatoma H22 tumor cell-bearing mouse model. Briefly, mice were injected with hepatoma $\mathrm{H} 22$ cells in the armpit respectively except the normal group mice. The recipient mice were randomly separated into five groups (each group 12 mice): a normal group, a negative control group, a positive control group and ASR ethanol extracts low- and high-dose groups. 5-Fu was given to the positive control group mice by intraperitoneal injection every other day. The negative control and normal groups were treated every day with normal saline only. The ASR ethanol extract low- and high-dose groups were administered with 1 and $5 \mathrm{~g} / \mathrm{kg}$ ethanol extract by gavage every day separately. After 10 days of treatment, all mice were sacrificed, and the tumors, spleens and thymus were excised for weighing. Spleen and thymus index is the ratio of spleen and thymus weight $(\mathrm{mg})$ to the body weight of the mouse $(\mathrm{g})$.

Statistical analysis. The experiments were performed at least 3 times. All values are presented as the means \pm standard error of the mean (SEM). Variance of P-values obtained was calculated by means of a single-factor analysis of variance (ANOVA) test. Differences were considered to indicate a statistically significant result, at $\mathrm{P}$-value $<0.05$.

\section{Results}

UPLC-Q-TOF MSE assay. Fig. 1 shows the UPLC-Q-TOF MS base peak ion (BPI) chromatograms of ASRE in negative 
Table II. $\mathrm{IC}_{50}$ values for ASRE extracts on the proliferation of different cell lines $(\mu \mathrm{g} / \mathrm{ml})$.

\begin{tabular}{ccccccr}
\hline & HepG2 & MG803 & PC3 & MCF7 & A549 & HL-7702 \\
\hline ASRE extract & $32.9 \pm 0.22$ & $35.6 \pm 2.47$ & $48.7 \pm 2.37$ & $55.8 \pm 8.9$ & $61.9 \pm 5.4$ & $>200$
\end{tabular}

Values represent the mean $\pm \mathrm{SD}(\mathrm{n}=3)$. $\mathrm{IC}_{50}$, concentration of $50 \%$ inhibition; ASRE, ethyl acetate extract from Ampelopsis sinica root.

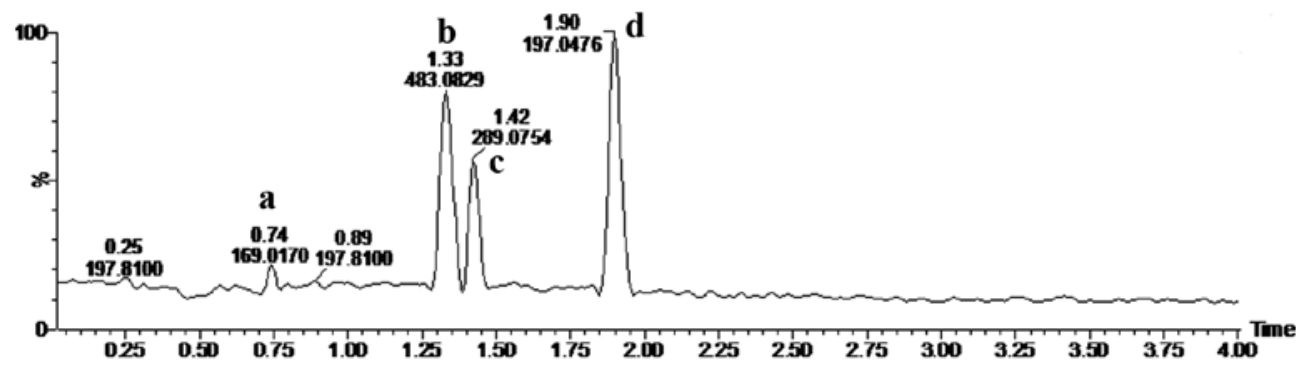

Figure 1. BPI chromatograms of A. sinica in negative mode. (a) Gallic acid; (b) 1,2-Bis-O-(3,4,5-trihydroxybenzoyl)- $\beta$-D-glucopyranose; (c) catechin; (d) gallic acid ethyl ester. BPI, base peak intensity.

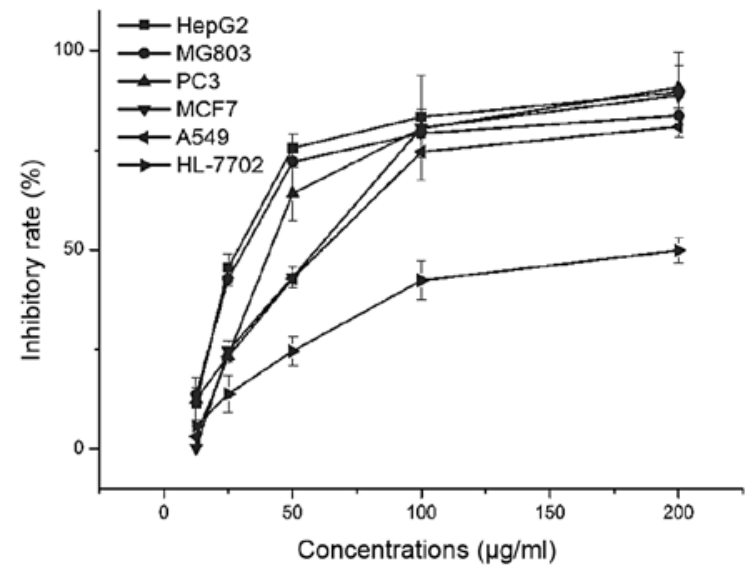

Figure 2. Inhibitory effect of ASRE on the proliferation of HepG2, MG803, PC3, MCF7, A549 and HL-7702 cells. Cells were treated with different concentrations of ASRE $(12.5,25,50,100$ and $200 \mu \mathrm{g} / \mathrm{ml})$ for $72 \mathrm{~h}$. Values are means $\pm \mathrm{SD}(\mathrm{n}=5)$. ASRE, ethyl acetate extract from Ampelopsis sinica root.

ESI-MS ${ }^{\mathrm{E}}$ mode. Four main peaks appeared in the chromatograms and their retention times (RT) were: $0.74,1.32,1.42$ and $1.898 \mathrm{~min}$, respectively. The quasi-molecular ions at $\mathrm{m} / \mathrm{z}$ 169.0170, 483.0829, 289.0754 and 197.0476 [M-H] in the negative ESI mode suggested the molecular formula $\mathrm{C}_{7} \mathrm{H}_{6} \mathrm{O}_{5}, \mathrm{C}_{20} \mathrm{H}_{20} \mathrm{O}_{14}, \mathrm{C}_{15} \mathrm{H}_{14} \mathrm{O}_{6}$ and $\mathrm{C}_{9} \mathrm{H}_{10} \mathrm{O}_{5}$. According to the molecular weight, related literature (12-15), and standard compound peaks, we initially speculated that $\mathrm{m} / \mathrm{z} 169.0170$, 289.0754 and 197.0476 [M-H] $^{-}$were gallic acid, catechin and gallic acid ethyl ester, respectively. Based on the main fragmentations of mass spectrums in negative ESI-MS ${ }^{\mathrm{E}}$ mode, we deduced that compound $\mathrm{C}_{20} \mathrm{H}_{20} \mathrm{O}_{14}$ was most likely 1,2-Bis-O-(3,4,5-trihydroxybenzoyl)- $\beta$-D-glucopyranose.

Cell viability assay. To evaluate the effect of ASRE on cell growth, the proliferation of five human tumor cell lines HepG2, PC3, MCF7, MG803, A549 and one normal cell HL-7702 were determined by MTT method. The $\mathrm{IC}_{50}$ values which quantitatively expressed the potency of ASRE in inhibiting the cancer cells are shown in Table II, the ASRE exhibited highest antitumor activity against the $\mathrm{HepG} 2$ cell $\left(\mathrm{IC}_{50}=32.9 \mu \mathrm{g} / \mathrm{ml}\right)$ compared to the other four tumor cells. In addition, for normal cell HL-7702 (normal human liver), ASRE had the lowest cytotoxicity compare to tumor cells. As shown in Fig. 2, ASRE reduced tumor cell viability in a dose-dependent manner and the viability of HepG2 cells was significantly affected when the cells were treated with ASRE at the concentration of $25 \mu \mathrm{g} / \mathrm{ml}$ or above.

The ASRE at doses up to $200 \mu \mathrm{g} / \mathrm{ml}$ caused no more than $50 \%$ growth inhibition of the normal HL-7702 cells. The MTT results identified that the ASRE has antitumor activity on human tumor cells, especially HepG2 cell, and lower cytotoxicity on normal cells than against the cancer cells.

Morphological changes of HepG2 cells induced by ASRE under inverted microscope. As shown in Fig. 3, marked morphological changes were observed as compared with untreated cells, while HepG2 cells were incubated with different doses of ASRE (25, 50 and $100 \mu \mathrm{g} / \mathrm{ml})$ for $24 \mathrm{~h}$. Untreated HepG2 cells attached closely on the culture in a homogeneous size with few floating cells and some of them contacted each other to form colonies (Fig. 3A). However, ASRE treated cells made fewer cellular contacts and became round in shape with shrunken nuclei. It was observed that the adherent cells were reduced and the floating cells increased. Furthermore, these cell morphological changes were dosedependent (Fig. 3B-D).

Hoechst 33258 staining. To analysis the effect of ASRE on the morphology of apoptotic cells, Hoechst 33258 staining test was conducted. After exposing to $100 \mu \mathrm{g} / \mathrm{ml}$ ASRE for $48 \mathrm{~h}$, distinct morphological changes in chromatin morphology such as crenation, condensation and fragmentation were observed in HepG2 cells (Fig. 4). 

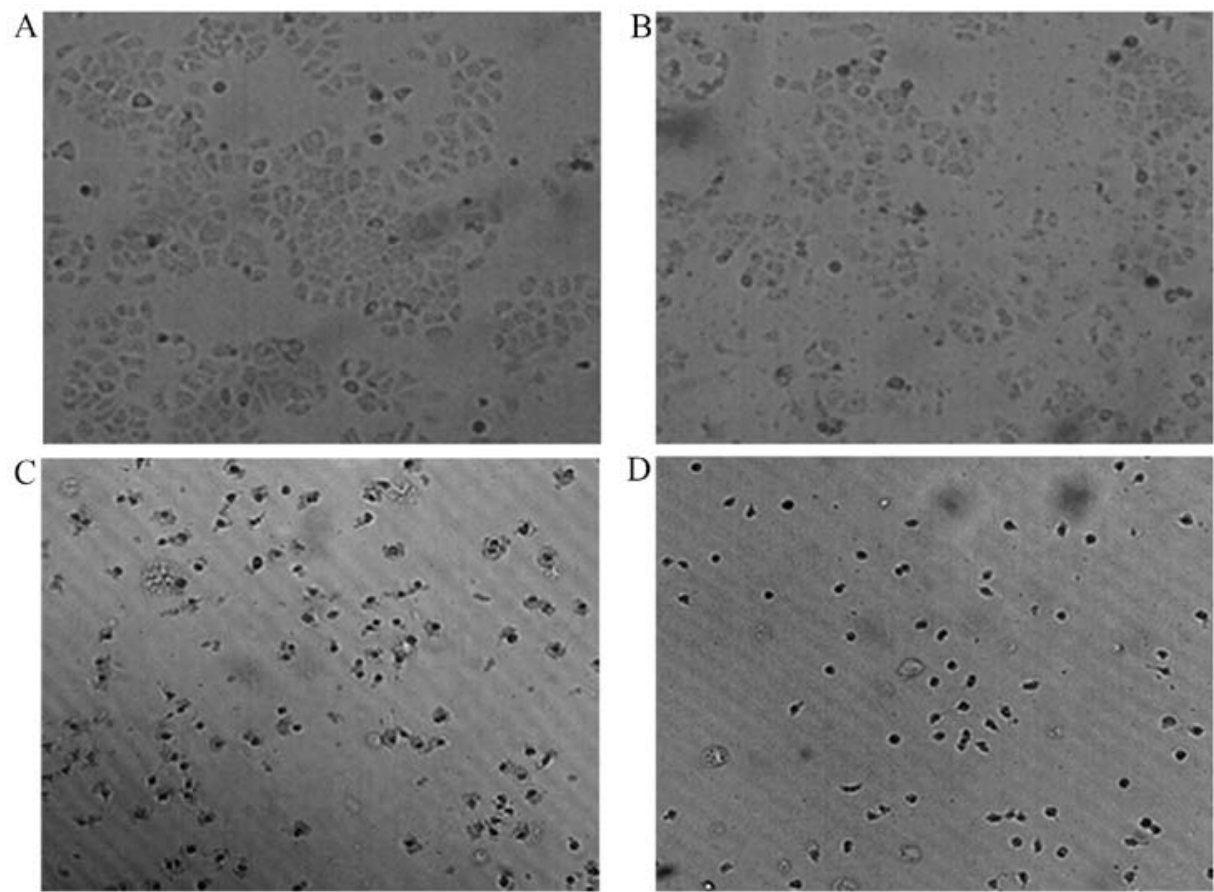

Figure 3. Morphological changes of HepG2 cells induced by different concentrations of ASRE. Changes of cellular morphology were examined at $24 \mathrm{~h}$ with x100 magnification. (A) Control; (B) $50 \mu \mathrm{g} / \mathrm{ml}$; (C) $75 \mu \mathrm{g} / \mathrm{ml}$; (D) $100 \mu \mathrm{g} / \mathrm{ml}$. ASRE, ethyl acetate extract from Ampelopsis sinica root.
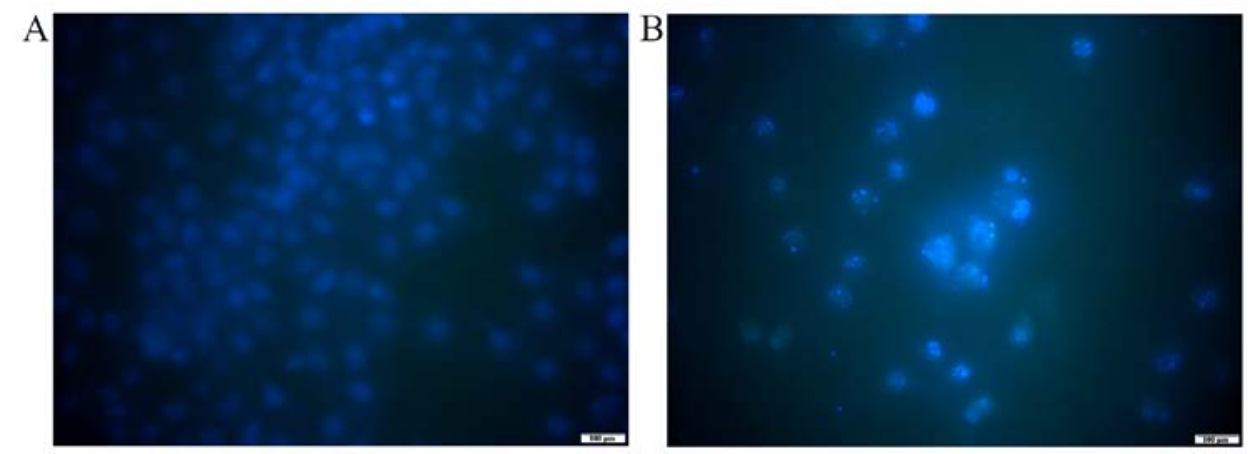

Figure 4. The Hoechst 33258 staining graph of HepG2 cells with x400 magnification. (A) HepG2 cells treated with no ASRE. (B) HepG2 cells treated with $100 \mu \mathrm{g} / \mathrm{ml}$ ASRE. ASRE, ethyl acetate extract from Ampelopsis sinica root.

SEM observation. The ultrastructural changes of HepG2 cells after respectively exposed to various concentrations $(0,50$, 75 and $100 \mu \mathrm{g} / \mathrm{ml}$ ) were observed under SEM. As shown in Fig. 5A-C, with the increase of the ASRE concentration, the treated cells became shrunken and displayed spheres, adherence was not good gradually, showed less or no microvilli, and formation of apoptotic bodies was observed (Fig. 5D).

ASRE induces apoptosis in HepG2 cells in vitro. To confirm whether ASRE induced cell death via apoptosis, the cells stained with Annexin V-FITC and PI were analyzed by flow cytometry. In the early stages of apoptosis, phosphatidylserine (PS) was everted from the internal layer to the outer face of the plasma membrane. Annexin V was functioned as a sensitive probe of apoptosis in early phase for its high affinity to PS on the cell membrane surface. The Annexin V-FITC and PI dual staining method has been widely used to differentiate viable cells (Annexin $\mathrm{V}^{-} / \mathrm{PI}^{-}$), early apoptotic cells (Annexin $\left.\mathrm{V}^{+} / \mathrm{PI}\right)$, late apoptotic cells $\left(\right.$ Annexin $\left.\mathrm{V}^{+} / \mathrm{PI}^{+}\right)$ and necrotic cells (Annexin $\mathrm{V}^{-} / \mathrm{PI}^{+}$). In this study, we accept the Annexin V-FITC positively stained (early and late stage of apoptosis) cells as apoptotic population. As shown in Fig. 6, the apoptosis population (\%) of HepG2 cells increased from 5.96 to $52.46 \%$ when ASRE concentration increased from 0 to $100 \mu \mathrm{g} / \mathrm{ml}$. Similarly, the apoptosis population (\%) of HepG2 cells increased from 5.95 to $39.97 \%$ when the acting time of ASRE increased from 0 to $24 \mathrm{~h}$ (Fig. 7). The results support time- and dose-dependent late apoptotic induction properties of ASRE on HepG2 cells.

Effect of ASRE on inflammation factors and apoptosis-related gene expression. To further explore the potential mechanism of ASRE on inhibiting cell growth and inducing apoptosis, mRNA expression of several inflammation-related genes and apoptosis-related genes were investigated by RT-PCR assay. As shown in Fig. 8, the level of COX-2, 5-LOX and FLAP mRNA was gradually decreased with the incubation time increasing from 0 up to $12 \mathrm{~h}$, which implied ASRE may 

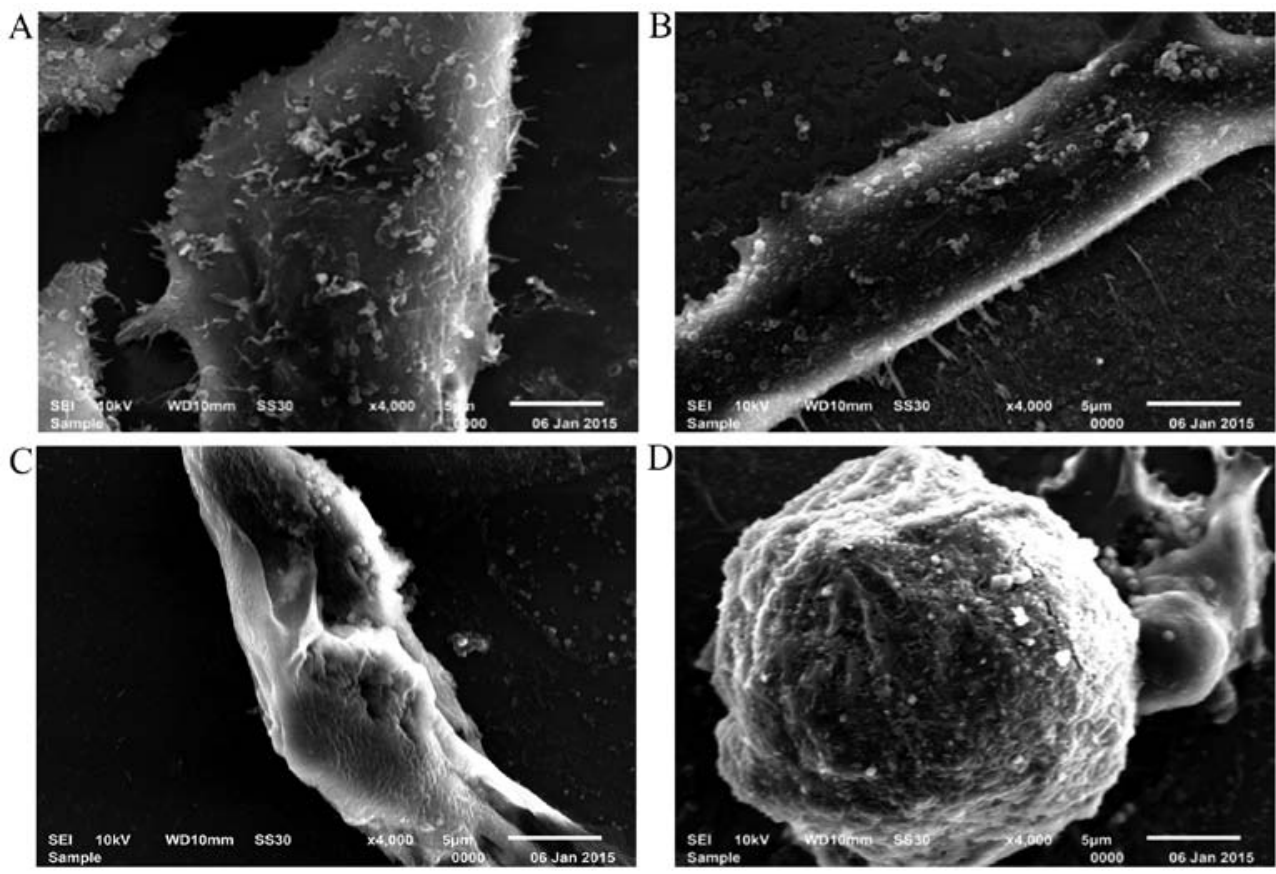

Figure 5. The SEM graphs of HepG2 cells after exposed to various concentrations of ASRE with x4,000 magnification. (A) $0 \mu \mathrm{g} / \mathrm{ml} ;$ (B) $50 \mu \mathrm{g} / \mathrm{ml}$; (C) $75 \mu \mathrm{g} / \mathrm{ml}$; (D) $100 \mu \mathrm{g} / \mathrm{ml}$. SEM, scanning electron microscopy; ASRE, ethyl acetate extract from Ampelopsis sinica root.
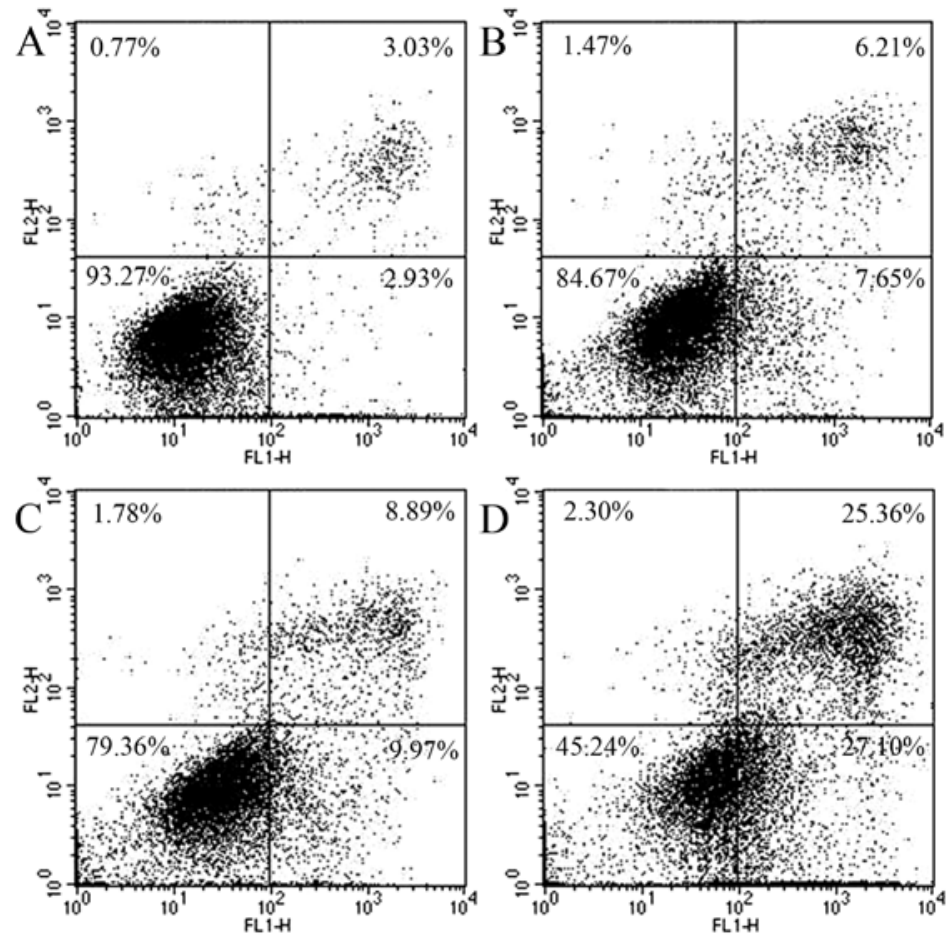

Figure 6. The HepG2 cells treated with different concentrations of ASRE were analyzed by flow cytometry. (A) $0 \mu \mathrm{g} / \mathrm{ml}$; (B) $50 \mu \mathrm{g} / \mathrm{ml}$; (C) $75 \mu \mathrm{g} / \mathrm{ml}$; (D) $100 \mu \mathrm{g} / \mathrm{ml}$. ASRE, ethyl acetate extract from Ampelopsis sinica root.

prevent inflammatory response related factors production at gene level. The treatment of ASRE on HepG2 cells for $12 \mathrm{~h}$ inhibited COX-2, 5-LOX and FLAP mRNA production up to $73.47,63.51$ and $60.82 \%$, respectively.

In another aspect, bax and bcl-2 are a pair of most valuable genes for research in bcl-2 family, and the ratio of bax/ bcl-2 determines whether a cell undergoes apoptosis. Caspase activation is known as a major step in apoptosis. Caspase-3 plays key role in the process of transmitting apoptosis signs, and survivin could be one of the most powerful anti-apoptosis factors discovered. Our data suggested that the mRNA expression of bax and caspase- 3 were upregulated by $\sim 1.48$ and 2.33-fold, respectively, while bcl-2 and survivin were downregulated by $\sim 66.14$ and $71.5 \%$, after treatment of ASRE 

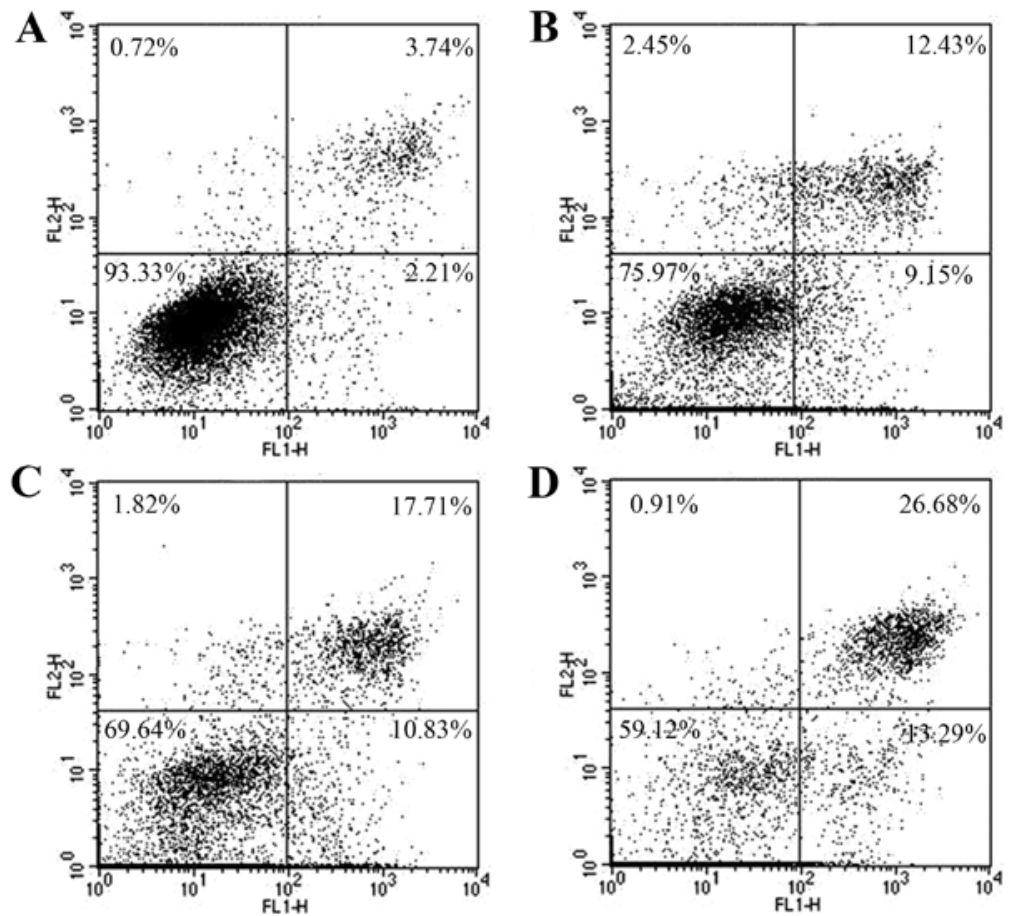

Figure 7. The HepG2 cells treated with different incubation times were analyzed by flow cytometry. (A) $0 \mathrm{~h}$; (B) $12 \mathrm{~h}$; (C) $18 \mathrm{~h}$; (D) $24 \mathrm{~h}$.

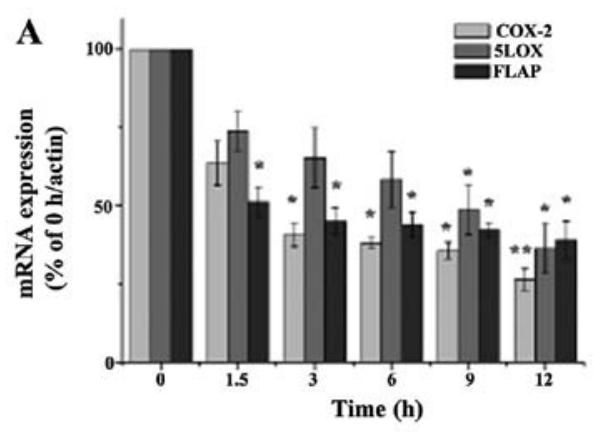

D
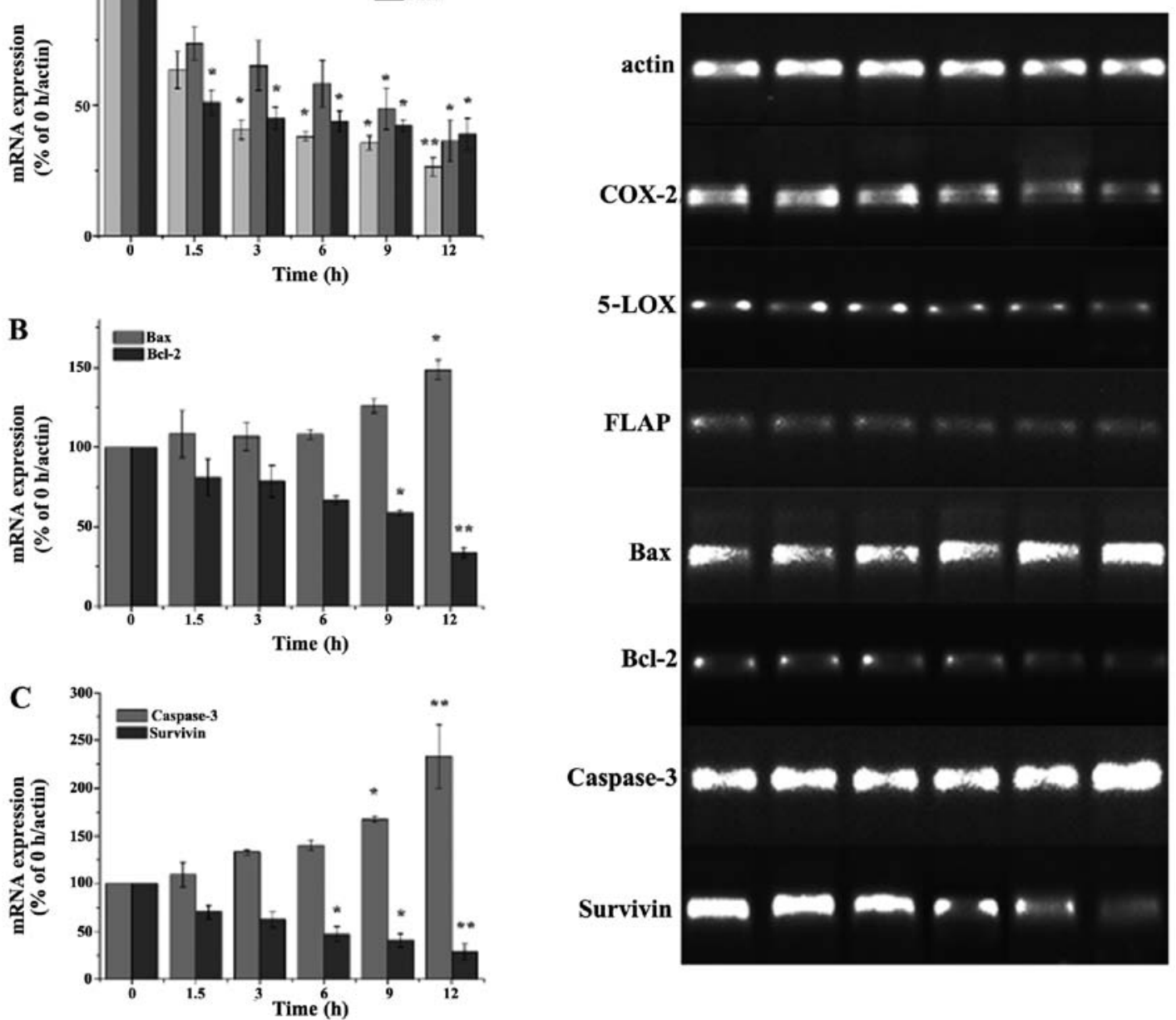

Figure 8. Effects of ASRE on COX-2, 5-LOX, FLAP, bax, bcl-2, caspase and survivin mRNA expression. (A-D) HepG2 cells were treated with ASRE for 0, 1.5, $3,6,9$ and $12 \mathrm{~h}$. Values are means $\pm \mathrm{SD}(\mathrm{n}=5)$. ${ }^{*} \mathrm{P}<0.05$ vs. the control group ${ }^{* * *} \mathrm{P}<0.01$ vs. the control group. ASRE, ethyl acetate extract from Ampelopsis sinica root; COX-2, cyclooxygenase-2; 5-LOX, 5-lipoxygenase. 

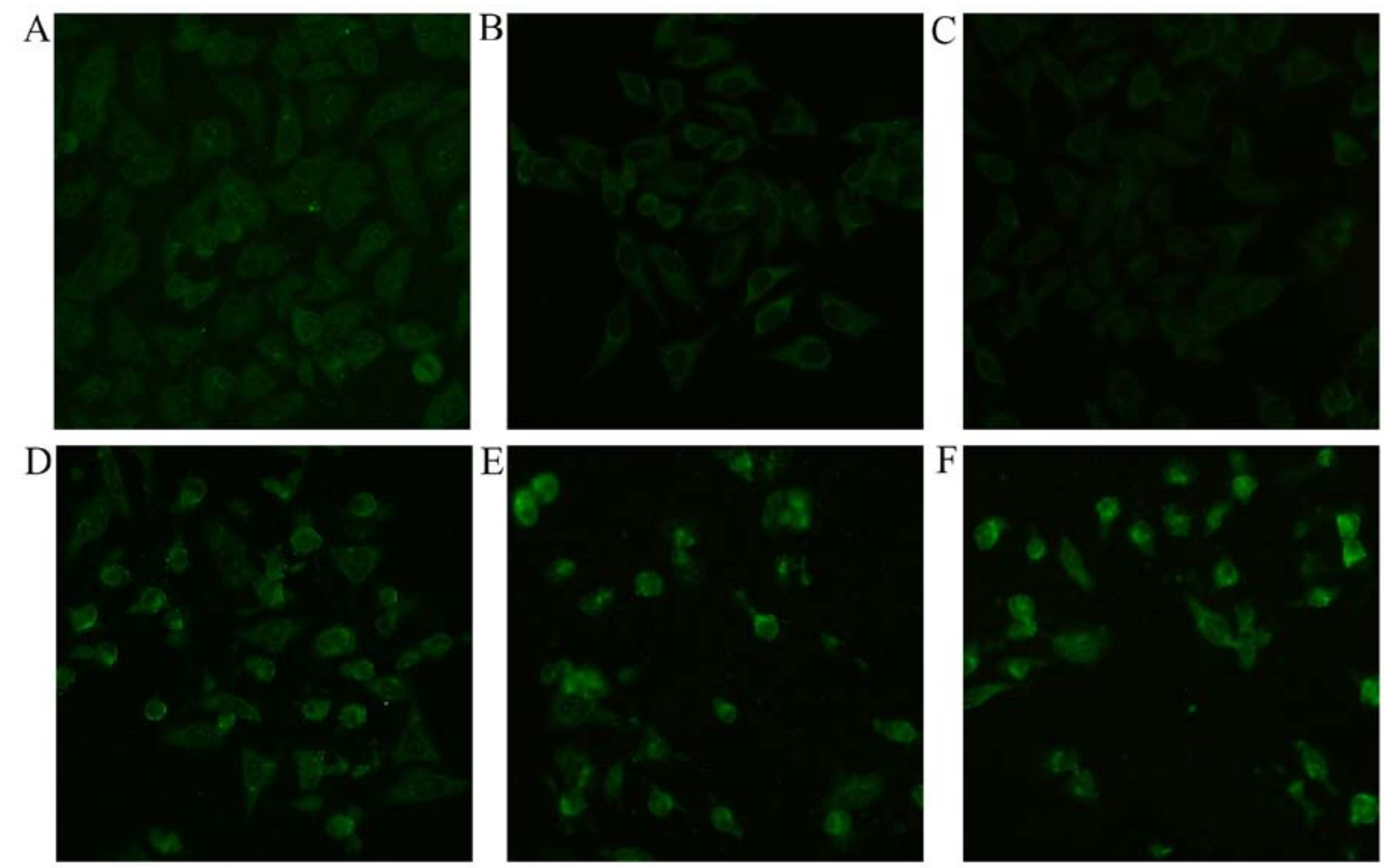

Figure 9. To further clarify the involvement of apoptosis pathway induced by ASRE in HepG2 cells, expression of apoptosis-related protein p53 was measured by immunofluorence stain. (A) Control (0 $\mu \mathrm{g} / \mathrm{ml}$ ASRE); (B) PBS (PBS replaced primary antibody); (C) $\beta$-actin ( $\beta$-actin replaced primary antibody); (D) $50 \mu \mathrm{g} /$ $\mathrm{ml}$ ASRE; (E) $75 \mu \mathrm{g} / \mathrm{ml}$ ASRE; (F) $100 \mu \mathrm{g} / \mathrm{ml}$ ASRE. ASRE, ethyl acetate extract from Ampelopsis sinica root.

Table III. Antitumor effects of ASR ethanol extracts against tumor growth on hepatoma $\mathrm{H} 22$ tumor-bearing mice.

\begin{tabular}{lcccc}
\hline Treatment & $\begin{array}{c}\text { Tumor } \\
\text { weight }(\mathrm{g})\end{array}$ & $\begin{array}{c}\text { Tumor growth } \\
\text { inhibition }(\%)\end{array}$ & $\begin{array}{c}\text { Spleen } \\
\text { index } \\
(\mathrm{mg} / 10 \mathrm{~g})\end{array}$ & $\begin{array}{c}\text { Thymus } \\
\text { index } \\
(\mathrm{mg} / 10 \mathrm{~g})\end{array}$ \\
\hline Control & $1.33 \pm 0.39$ & & $5.96 \pm 1.08$ & $2.01 \pm 0.65$ \\
ASR & & & & \\
$1 \mathrm{~g} / \mathrm{kg}$ & $1.03 \pm 0.30$ & 27.00 & $5.44 \pm 1.02$ & $1.97 \pm 0.60$ \\
$5 \mathrm{~g} / \mathrm{kg}$ & $0.54 \pm 0.27^{\mathrm{b}}$ & 59.14 & $5.70 \pm 0.60$ & $1.97 \pm 0.60$ \\
$5-\mathrm{Fu}$ & $0.53 \pm 0.27^{\mathrm{b}}$ & 60.24 & $4.68 \pm 0.94^{\mathrm{b}}$ & $1.78 \pm 0.60^{\mathrm{a}}$ \\
\hline
\end{tabular}

Values represent mean $\pm \mathrm{SE}$. ${ }^{\mathrm{a}} \mathrm{P}<0.05$ vs. the control group; ${ }^{\mathrm{b}} \mathrm{P}<0.01$ vs. the control group. ASR, Ampelopsis sinica root.

for $12 \mathrm{~h}$. In addition, the mRNA expression levels of bax, bcl-2, caspase- 3 and survivin change regularly with the action time of ASRE extending to $12 \mathrm{~h}$.

Immunofluorescence assay. To further clarify the involvement of apoptosis pathway induced by ASRE in HepG 2 cells, expression of apoptosis-related protein p53 was measured by immunofluorence stain. Fig. 9 clearly illustrates that the fluorescence intensity increased with the increasing of ASRE concentration, which revealed ASRE treatment resulted in upregulation of the tumor suppressor protein p53 expression.

Antitumor activity in vivo. Due to the good antitumor activities in vitro of ASRE, we conducted animal research to

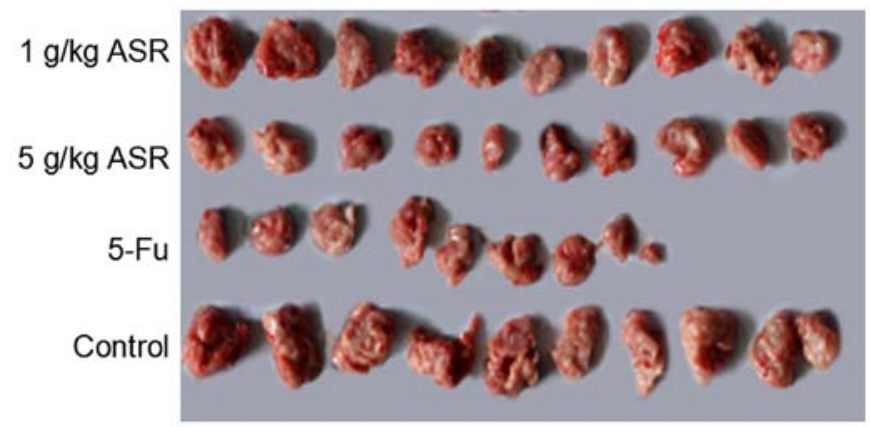

Figure 10. Antitumor effects of ASR ethanol extracts against tumor growth on hepatoma H22 tumor-bearing mice. ASR, Ampelopsis sinica root.

evaluate the antitumor effect of ASR ethanol extract in vivo. As daily observation, no mouse died when treated with ASR ethanol extracts below the dosages of $5 \mathrm{~g} / \mathrm{kg} / \mathrm{day}$. The effects of ASR ethanol extract on mice transplanted with hepatoma $\mathrm{H} 22$ are presented in Table III. The inhibitory rates were 27.00 and $59.14 \%$ at the dosages of $1,5 \mathrm{~g} / \mathrm{kg} / \mathrm{day}$, respectively. The results revealed that the higher dose ASR ethanol extracts $(5 \mathrm{~g} / \mathrm{kg} /$ day $)$ significantly decreased the tumor weights of $\mathrm{H} 22$ tumor-bearing mice compared to the control group $(\mathrm{P}<0.01)$. Furthermore, ASR ethanol extracts did not decrease the spleen and thymus index of the tumor-bearing mice (Table III; Fig. 10).

\section{Discussion}

The majority of HCC cases arise in the setting of underlying liver disease, such as chronic hepatitis B or C which lead to 
inflammation-induced lesions in the liver, hepatic fat accumulation, progressive fibrosis and irreversible cirrhosis (16-18). Studies worldwide have indicated that the extract of ASR has significant effect on hepatoprotection, descending transaminase, anti-hepatitis B virus, and suppressing free radical damage (2-6). Thus, we hypothesized that ASR had anti-hepatoma activity. The findings in this study showed that ASRE had dose-dependent antitumor activity against various tumor cells, especially on HepG2 cells $\left(\mathrm{IC}_{50}=32.9 \mu \mathrm{g} / \mathrm{ml}\right)$, and was less harmful to HL-7702 cells $\left(\mathrm{IC}_{50}>150 \mu \mathrm{g} / \mathrm{ml}\right)$ than the tested tumor cells, which indicated that ASRE inhibited proliferation of cancer cells selectively.

To date, several phytocompounds have been isolated from ASR, and both the pure compounds and crude extracts have displayed antioxidative effects and anti-inflammatory activities (2). The ethyl acetate portion of ASR showed stronger antitumor activity in pre-test than other portions probably due to the principal polyhydroxylphenolic compounds, such as gallic acid and catechin. Previous studies have indicated that gallic acid (an important phytochemical in pomegranates) and catechin (the primary phytochemical in green tea) have cancer-preventing activities in a variety of cancer cell types (19-22), and their cancer-preventing activities have a certain relationship with their antioxidant and anti-inflammatory activities (23-26). According to our experiment and literature, ASRE was found to exhibit higher anti-hepatoma activity than both gallic acid $\left(\mathrm{IC}_{50}=106.85 \mu \mathrm{g} / \mathrm{ml}\right)(27)$ and catechin which inhibited the growth of HepG2 cell lines at a concentration of $100-200 \mu \mathrm{g} / \mathrm{ml}$ (28). Similar results were seen in co-treatment of catechin and caffeine which resulted in a greater degree of cell inhibition than catechin or caffeine alone (29). Thus, further research on testing the effects of catechin and gallic acid in combination are needed.

The close association between cancer and chronic inflammation has been recognized for centuries. COX-2, 5-LOX and FLAP have been confirmed to be associated with occurrence, development and metastasis of several kinds of human tumors (30-32). Research has shown that excessive expression of COX-2 which plays its carcinogenesis role by inhibiting apoptosis, promoting cell division and proliferation, accelerating angiogenesis and blocking cell cycle (33-35) is emerged in malignant tumors, such as human breast cancer, esophageal squamous cell carcinomas, prostate cancer and colon cancer (36-39). Several groups have shown that 5-LOX pathway plays an important role in tumor growth $(40,41)$. As a 5-LOX activating protein, FLAP plays an important role in 5-LOX activity (42). Based on the RT-PCR results, the level of COX-2, 5-LOX and FLAP mRNA was gradually decreased with the incubation time after ASRE treatment, it is likely that the inhibitory effect of ASRE on HepG2 cell is associated with its anti-inflammatory properties.

The process of apoptosis is complex, and it is well-known that there are two main apoptotic signaling pathways, the mitochondria-mediated pathway and the death receptor-mediated pathway. In mitochondrial-mediated apoptosis pathway, the bcl-2 family members such as pro-apoptotic member bax and anti-apoptotic member bcl-2 have been considered to be vital regulators and the ratio of bax/bcl-2 largely determines whether cells will experience apoptosis (43-45). The mitochondria and the death receptor-mediated pathways converge to caspase-3, the activation of which means cells would undergo apoptosis unavoidably. p53 functions as a transcription factor regulating downstream genes important in cell cycle arrest, DNA repair, and apoptosis, loss of p53 in many cancers leads to apoptosis inhibition (46). In our study, ASRE treatment resulted in an upregulation of bax and downregulation of bcl-2, increased the ratio of bax/bcl-2, activated caspase- 3 and promoted p53 protein expression. Combined with the findings in our experimental study, it could be assumed that ASRE lead to apoptosis of cancer cells through inflammatory cytokines mediated pathway and mitochondria-mediated pathway. Increasing expression of $\mathrm{p} 53$ protein after ASRE treatment indicated the antitumor mechanisms of ASRE are also connected to the upregulation of p53 protein.

In conclusion, the present study demonstrated that ASRE has a powerful anticancer activity in vitro and in vivo without obvious toxicity. The mechanism of apoptosis induced by ASRE may be associated with downregulation of inflammatory cytokines including COX-2, 5-LOX and FLAP, the increase of the ratio of bax/bcl-2, activation of caspase-3 and inhibition of survivin, and the increasing expression of $\mathrm{p} 53$ protein, may provide experimental evidence for the possibility of ASRE being a potential therapeutic agent in the treatment and/or prevention of HCC.

\section{Acknowledgements}

This study was supported by Natural Science Foundation of Hubei Province of China (96J099), New Products of TCM Senile Diseases Co-Innovation Center of Hubei.

\section{References}

1. Yang LL, Yen KY, Kiso Y and Hikino H: Antihepatotoxic actions of Formosan plant drugs. J Ethnopharmacol 19: 103-110, 1987.

2. Chen K, Plumb GW, Bennett RN and Bao Y: Antioxidant activities of extracts from five anti-viral medicinal plants. J Ethnopharmacol 96: 201-205, 2005.

3. Chen K and Yang Z: The acting part anti HSV-1 in infected cells of extract from Ampelopsis sinica roots. J Chin Druggist 2: 225-226, 1999.

4. Chen K, Li H, Chen $\mathrm{Y}$ and Zhang C: Inhibition of extracts of Ampelopsis sinica roots on DHBVsAg in sera of ducklings. Zhong Yao Cai 23: 41-42, 2000 (In Chinese).

5. Pang R, Tao JY, Zhang SL, Chen KL, Zhao L, Yue X, Wang YF, Ye P, Zhu Y and Wu JG: Ethanol extract from Ampelopsis sinica root exerts anti-hepatitis B virus activity via inhibition of p53 pathway in vitro. Evid Based Complement Alternat Med 2011: 939205, 2011.

6. Chen KL, Zhang XM, Li HM and Zhang CZ: Anti-hepatic injury induced by D-GalN of three kinds of Radix Ampelopsis Sincae. Zhong Yao Cai 7: 353-354, 1999 (In Chinese).

7. Mosmann T: Rapid colorimetric assay for cellular growth and survival: application to proliferation and cytotoxicity assays. J Immunol Methods 65: 55-63, 1983.

8. Liu F, Wang JG, Wang SY, Li Y, Wu YP and Xi SM: Antitumor effect and mechanism of Gecko on human esophageal carcinoma cell lines in vitro and xenografted sarcoma 180 in Kunming mice. World J Gastroenterol 14: 3990-3996, 2008.

9. Qi FH, Li AY, Lv H, Zhao L, Li JJ, Gao B and Tang W: Apoptosis-inducing effect of cinobufacini, Bufo bufo gargarizans Cantor skin extract, on human hepatoma cell line BEL-7402. Drug Discov Ther 2: 339-343, 2008.

10. Pesce M and De Felici M: Apoptosis in mouse primordial germ cells: a study by transmission and scanning electron microscope. Anat Embryol (Berl) 189: 435-440, 1994.

11. Wong ML and Medrano JF: Real-time PCR for mRNA quantitation. Biotechniques 39: 75-85, 2005. 
12. Cheng QR, Chen KL and Ye CJ: The comparative study on the chemical components of four kinds of Ampelopsis sinica roots. Asia-Pacific Traditi Med 3: 55-56, 2007.

13. Xu ZH, Liu X and Xu G: Research on chemical constituents of Ampelopsis sinica root. J Tradit Chinese Med 8: 484-485, 1995 (In Chinese).

14. Yang L, Chen KL and Ye CJ: The quality standard of Ampelopsis sinica root ointment. J Central South Univ National (Natural Science Edition) 26: 26-29, 2007.

15. Chen KL: Research on chemical constituents of Ampelopsis sinica root. J Tradit Chinese Med 5: 294-295, 1996 (In Chinese).

16. Chen VL, Le AK, Kim NG, Kim LH, Nguyen NH, Nguyen PP, Zhao C and Nguyen MH: Effects of cirrhosis on short-term and long-term survival of patients with hepatitis B-related hepatocellular carcinoma. Clin Gastroenterol Hepatol 14: 887-895, 2016.

17. Vescovo T, Refolo G, Vitagliano G, Fimia GM and Piacentini M: Molecular mechanisms of hepatitis $\mathrm{C}$ virus-induced hepatocellular carcinoma. Clin Microbiol Infect 22: 853-861, 2016.

18. Arzumanyan A, Reis HM and Feitelson MA: Pathogenic mechanisms in HBV- and HCV-associated hepatocellular carcinoma. Nat Rev Cancer 13: 123-135, 2013.

19. Zhang D, Al-Hendy M, Richard-Davis G, Montgomery-Rice V, Sharan C, Rajaratnam V, Khurana A and Al-Hendy A: Green tea extract inhibits proliferation of uterine leiomyoma cells in vitro and in nude mice. Am J Obstet Gynecol 202: 289, 2010.

20. Mak JC: Potential role of green tea catechins in various disease therapies: progress and promise. Clin Exp Pharmacol Physiol 39: 265-273, 2012

21. Kawada M, Ohno Y, Ri Y, Ikoma T, Yuugetu H, Asai T, Watanabe M, Yasuda N, Akao S, Takemura G, et al: Anti-tumor effect of gallic acid on LL-2 lung cancer cells transplanted in mice. Anticancer Drugs 12: 847-852, 2001.

22. You BR and Park WH: Gallic acid-induced lung cancer cell death is related to glutathione depletion as well as reactive oxygen species increase. Toxicol In Vitro 24: 1356-1362, 2010.

23. Lambert JD and Elias RJ: The antioxidant and pro-oxidant activities of green tea polyphenols: a role in cancer prevention. Arch Biochem Biophys 501: 65-72, 2010.

24. Saito Y, Shimada M, Utsunomiya T, Imura S, Morine Y, Ikemoto T, Mori V, Hanaoka J and Kanamoto M: Green tea catechins improve liver dysfunction following massive hepatectomy through anti-oxidative and anti-inflammatory activities in rats. Gastroenterology 140: S928, 2011.

25. Inoue $M$, Sakaguchi $N$, Isuzugawa $K$, Tani $H$ and Ogihara $Y$ Role of reactive oxygen species in gallic acid-induced apoptosis. Biol Pharm Bull 23: 1153-1157, 2000.

26. Locatelli C, Filippin-Monteiro FB, Centa A and Creczinsky-Pasa TB: Antioxidant, antitumoral and anti-inflammatory activities of gallic acid. In: Handbook on Gallic Acid: Natural Occurrences, Antioxidant Properties and Health Implications. Thompson MA and Collins PB (eds). 4th Edition. Nova Science Publishers, Hauppauge, NY, pp1-23, 2013.

27. Lim FPK, Bongosia LFG, Yao NBN and Santiago LA: Cytotoxic activity of the phenolic extract of virgin coconut oil on human hepatocarcinoma cells (HepG2). Int Food Res J 21: 729-733, 2014.

28. Jain P, Kumar N, Josyula VR, Jagani HV, Udupa N, Mallikarjuna-Rao C and Vasanth-Raj P: A study on the role of (+)-catechin in suppression of HepG2 proliferation via caspase dependent pathway and enhancement of its in vitro and in vivo cytotoxic potential through liposomal formulation. Eur J Pharm Sci 50: 353-365, 2013.

29. Haddad L and Rowland-Goldsmith M: Assessment of the effects of caffeine, gallic acid, and epigallocatechin-3-gallate on cell inhibition, PIM-3 and E. cadherin protein levels in two lines of pancreatic cancer cells. Presented at the Fall 2014 Undergraduate Student Research Day at Chapman University. Student Research Day Abstracts and Posters: 76, 2014. http://digitalcommons. chapman.edu/cusrd_abstracts/76.
30. Rao CV, Janakiram NB and Mohammed A: Lipoxygenase and cyclooxygenase pathways and colorectal cancer prevention. Curr Colorectal Cancer Rep 8: 316-324, 2012.

31. Schneider C and Pozzi A: Cyclooxygenases and lipoxygenases in cancer. Cancer Metastasis Rev 30: 277-294, 2011.

32. Fürstenberger G, Krieg P, Müller-Decker K and Habenicht AJ: What are cyclooxygenases and lipoxygenases doing in the driver's seat of carcinogenesis? Int J Cancer 119: 2247-2254, 2006.

33. Sun Y, Tang XM, Half E, Kuo MT and Sinicrope FA: Cyclooxygenase-2 overexpression reduces apoptotic susceptibility by inhibiting the cytochrome $c$-dependent apoptotic pathway in human colon cancer cells. Cancer Res 62: 6323-6328, 2002.

34. Yao L, Liu F, Hong L, Sun L, Liang S, Wu K and Fan D: The function and mechanism of COX-2 in angiogenesis of gastric cancer cells. J Exp Clin Cancer Res 30: 13, 2011.

35. Trifan OC, Smith RM, Thompson BD and Hla T: Overexpression of cyclooxygenase-2 induces cell cycle arrest. Evidence for a prostaglandin-independent mechanism. J Biol Chem 274: 34141-34147, 1999.

36. Jiang WG, Douglas-Jones A and Mansel RE: Levels of expression of lipoxygenases and cyclooxygenase-2 in human breast cancer. Prostaglandins Leukot Essent Fatty Acids 69: 275-281, 2003.

37. Takatori H, Natsugoe S, Okumura H, Matsumoto M, Uchikado Y, Setoyama T, Sasaki K, Tamotsu K, Owaki T, Ishigami S, et al: Cyclooxygenase- 2 expression is related to prognosis in patients with esophageal squamous cell carcinoma. Eur J Surg Oncol 34: 397-402, 2008.

38. Yoshimura R, Sano H, Masuda C, Kawamura M, Tsubouchi Y, Chargui J, Yoshimura N, Hla T and Wada S: Expression of cyclooxygenase-2 in prostate carcinoma. Cancer 89: 589-596, 2000.

39. Ogino S, Kirkner GJ, Nosho K, Irahara N, Kure S, Shima K, Hazra A, Chan AT, Dehari R, Giovannucci EL, et al: Cyclooxygenase-2 expression is an independent predictor of poor prognosis in colon cancer. Clin Cancer Res 14: 8221-8227, 2008.

40. Romano M and Claria J: Cyclooxygenase-2 and 5-lipoxygenase converging functions on cell proliferation and tumor angiogenesis: implications for cancer therapy. FASEB J 17: 1986-1995, 2003.

41. Ghosh J and Myers CE: Arachidonic acid stimulates prostate cancer cell growth: critical role of 5-lipoxygenase. Biochem Biophys Res Commun 235: 418-423, 1997.

42. Datta K, Biswal SS and Kehrer JP: The 5-lipoxygenase-activating protein (FLAP) inhibitor, MK886, induces apoptosis independently of FLAP. Biochem J 340: 371-375, 1999.

43. Ghosh J and Myers CE: Inhibition of arachidonate 5-lipoxygenase triggers massive apoptosis in human prostate cancer cells. Proc Natl Acad Sci USA 95: 13182-13187, 1998.

44. Hu W, Lee SK, Jung MJ, Heo SI, Hur JH and Wang MH: Induction of cell cycle arrest and apoptosis by the ethyl acetate fraction of Kalopanax pictus leaves in human colon cancer cells. Bioresour Technol 101: 9366-9372, 2010.

45. Sun B, Geng S, Huang X, Zhu J, Liu S, Zhang Y, Ye J, Li Y and Wang J: Coleusin factor exerts cytotoxic activity by inducing G0/G1 cell cycle arrest and apoptosis in human gastric cancer BGC-823 cells. Cancer Lett 301: 95-105, 2011.

46. Qi F, Li A, Inagaki Y, Xu H, Wang D, Cui X, Zhang L, Kokudo N, Du G and Tang W: Induction of apoptosis by cinobufacini preparation through mitochondria- and Fas-mediated caspase-dependent pathways in human hepatocellular carcinoma cells. Food Chem Toxicol 50: 295-302, 2012. 